\title{
An Audience's Subjective Experience of the Freedom of Artistic Expression in Different Dance Forms from the Perspective of the Cultural Psychology of Creativity*
}

\author{
La experiencia subjetiva del observador sobre la libertad de \\ expresión artística en las formas diferentes de la danza: un \\ enfoque desde la psicología cultural de la creatividad
}

Recibido: enero 23 de 2012 | Revisado: agosto 4 de 2012 | Aceptado: diciembre 18 de 2012

\author{
Maja VuKadinOvić ** \\ Higher School of Professional Business Studies, Serbia
}

doi:10.11144/Javeriana.UPSY12-3.asef

Para citar este artículo: Vukadinović, M. (2013). An audience's subjective experience of the freedom of artistic expression in different dance forms from the perspective of the cultural psychology of creativity. Universitas Psychologica, 12(3), 709-723. doi:10.11144/Javeriana.UPSY12-3.asef

\footnotetext{
Based on the context of the cultural psychology of creativity this study refers to the investigation of the audience's experience of the freedom of artistic expression in different dance forms: classical ballet, modern ballet and flamenco.

** Higher School of Professional Business Studies, Novi Sad, Serbia. Researcher ID: H-8078-2013. Novi Sad Center for Dance Research and Art of Flamenco - La Sed Gitana. E-mail: 1lubicica@ gmail.com
}

\section{A B S T R A C T}

Previous studies on different dance forms, including classical ballet, modern ballet and flamenco, show that the objective classification of these forms of dance is subjectively relevant, or in other words, the subjective categorization of dance is based on its formal properties. Based on this standpoint, this study aims to examine the audience's subjective experience of the freedom of artistic expression in three dance forms: classical ballet, modern ballet and flamenco. This study also aims to place an audience's subjective experience of the freedom of artistic expression in different dance forms, into the context of the cultural psychology of creativity. Sixtynine participants assessed three choreographies from each dance form. The participants observed the choreographies audio-visually. The assessment of the freedom of artistic expression included seven-point scales of freedom to use space, use different figures and to express different emotions. The results showed that the dance form effects the assessment of an audience's subjective experiences (using these 3 criteria) in relation to the freedom of artistic expression. Likewise, Choreography has a marked effect on the assessment of subjective experience within the aforementioned criteria for the freedom of artistic expression within each observed dance form. In conclusion, a dance form determines, by its formal characteristics, not only how certain choreography will be created, but also how an audience will experience the choreography. The various implications of the research results on creativity in the field of dance, and the importance of understanding the complex dialogical connections between particular dance forms, choreographers, choreographies and audience in the context of the cultural psychology of creativity were discussed.

Key words author

Subjective experience, dance, the freedom of artistic expression, university students (audience).

Key words plus

Social and Cultural Psychology, Qualitative Research, Creativity.

\section{RESUMEN}

Este artículo tiene por objeto examinar la experiencia subjetiva del observador de la libertad de expresión artística en tres formas de danza: ballet clásico, ballet moderno y baile flamenco; adicionalmente, pretende situar la investigación en el contexto de la psicología cultural de la creatividad. Los 69 participantes evaluaron tres coreografías para cada forma de danza, 
observándolas a través de audiovisuales. La estimación de la libertad de expresión artística incluye tres escalas de siete puntos: libertad de usar el espacio, libertad de utilizar diferentes figuras y libertad para expresar sus emociones. Los resultados muestran que la forma de danza tiene un efecto significativo sobre la estimación de la experiencia subjetiva de estos tres criterios y que la coreografía tiene un marcado efecto sobre la estimación de la experiencia subjetiva sobre la libertad de expresión artística dentro de cada forma de la danza observada. Los resultados sugieren que una forma de danza determina, por sus características formales, no solo la coreografía, o cómo se creará, sino también cómo un observador experimentará la coreografía creada. Se discuten las diversas implicaciones de los resultados en la creatividad en el área de la danza, y la importancia de entender las conexiones complejas y dialógicas entre forma particular de danza, coreógrafo, coreografía y observadores, en el contexto de la psicología cultural de la creatividad.

Palabras clave autor

Experiencia subjetiva, danza, libertad de expresión artística, estudiantes universitarios (observadores), psicología cultural de la creatividad.

Palabras clave descriptores

Psicología cultural y social, investigación cualitativa, creatividad.

From a relatively new perspective (Glăvaneu, 2010) three paradigms in creativity theory and research in psychology can be defined. According to Glăvaneu (2010), recent studies and research on creativity have been focused on the solitary genius ( $\mathrm{He}-$ paradigm) or on individual cognitive processes and creative person (I - paradigm) but since Glăvaneu (2010) introduced We - paradigm the focus on studying creativity has expanded, and it now involves cultural and social context.

Creativity, seen as a type of useful and effective reply to evolutionary changes that enable a person to become flexible, would include a set of characteristics where originality and flexibility are important constituents (Runco, 2001, 2004). However, taking into account the wider context of cultural perspective (Glăvaneu, 2010), creativity should be defined as a complex socio-culturalpsychological process.

The starting point in defining a problem is the assumption that studies on creativity may be classified (Runco, 2004) into studies dealing with person, creative process itself, press and product. This paper is related to a specific domain - the domain of dance and it employs product approach (Runco,
2004) to creativity, which is based on examining the results of creative process.

Since creativity accompanies all aspects of dance, from choreography to performance via dance education, creativity in the field of dance has been studied from these different aspects (see more in Press \& Warburton, 2007). The results of different studies on creativity in choreography were summarized by Hagood and Kahlich (2007). Various authors (DeLahunta, 2004; Stevens, Malloch, \& McKechnie, 2001; Stevens, Malloch, McKechnie, \& Steven, 2003) studied links between choreography and cognition, there is also special research dealing with the field of psychotherapy and the psychotherapeutic effects of dance and spontaneous dance (Meekums, 2005; Pallaro, 1999, 2007).

Artistic dance, compared to spontaneous rhythmic dance, is defined as a specific type of complex and highly articulated movement, or in other words, as a system of organized and formalized movements conveying a meaning which an artist expresses consciously and transfers to an audience on purpose (Blom \& Chaplin, 2000; Duncan, 1981; Meekums, 2005; Stevens et al., 2001; Tufnel \& Cricmay, 2006). In order to have dance experienced and appreciated as art, the concept characterizing each dance (Adshead, Briginshaw, Hodgens, \& Huxley, 1982) will mean that certain dance is choreographed, performed and appraised (Adshead et al., 1982; Kogan, 2002) by its choreographer, then by the performer and finally by the audience. It can be seen that artistic dance is inextricably bound to the importance of dancing context (Layson, 1994; McFee, 1992) in which the attendance of an audience is essential to have dance, defined as a performing art.

The fact that dance is related to specific dancing contexts which in a narrow sense presumes the attendance of an audience (Layson, 1994; McFee, 1992), and in a broader sense refers to the dependency of dance on the social, cultural and historical contexts in which it originates and takes place (Adshead-Lansdale \& Layson, 1994; Fraleigh, 1999), leads to the perspective of cultural psychology of creativity (Glăvaneu, 2010) as a complete and comprehensive approach in understanding the dance. 
Within the "tetradic framework of creativity", Glăvaneu (2010) observes the relationship between self (creator), other (community), new artefact (creation) and existing artefacts (culture) as a dynamic whole, insisting on a dialogical connection between them. This author (Glăvaneu, 2010, p. 87) also emphasizes that creativity cannot exist outside the relationship with other people, and that creativity has to be inside a cultural setting since every new artefact needs constant meaning-making processes. In the context of artistic dance, creation (new artefact) would relate to the specific choreographies of the certain dance forms, made by Choreographers (creator) respecting the rules and in accordance with the norms and ideas of a dance form they belong to, and represented in front of the audience (other).

The main assumption of this research is that within dance as a specific artistic discipline, the system of symbols and norms that constitute particular dance forms shape through its formal characteristics not only how the choreography (new artefact) is created (by choreographer-creator) but also how an audience (other) experiences it.

Since the main focus of this research is on the audience (other) and how they experience the specific characteristics of dance, referring to the freedom of artistic expression, the idea of freedom in dance and especially the freedom of artistic expression will all be explained forthwith.

Psychologically speaking, dance encompasses a set of experiences relating to the strength of the body, its position and movements, its spatial orientation as well as the interior sense of a dancers' muscles, joints and tendons (Fenemor, 2003; Golomer \& Dupui, 2000; Hamby, 1984; Hugel, Cadopi, Kohler, \& Perrin, 1999; Montero, 2006; Mullis, 2006; Thomas, 1980) so dance is a type of kinaesthetic art or "art of the muscular sense" as suggested by Arnheim (1966, p. 261). Joy and satisfaction, self-worth, feelings of strength and freedom of body, the feeling of space, liberty and beauty may be recognized as psychological spin-offs of dance (Biddle, Fox, \& Boutcher, 2000; Biddle \& Mutrie, 2001; Kent, Camner, \& Camner, 1984; Kogan, 2002). It can be said that an experience of freedom is something that characterizes art, and thus dance. "The theory of dynamic competences" (Ognjenović, 2003) recognizes the sense of art in the regeneration of system flexibility, a return to the possibilities of decision-making, giving a fair chance to an individual's potentials. In other words, the art of dance as well as art in general are "regainer of freedom in using oneself" (Ognjenović, 2003, p. 238).

Artistic creativity, observed from the aspect of implicit theories on creativity (Runco \& Bahleda, 1986), would involve emotions, imagination and expressiveness. Freedom in dance is often related to artistic expression. Thus, Arnold (1986) observes dance as a form of artistic self-expression. In addition to freedom and discipline that should be well-balanced (Arnold, 1986), self-expression of aesthetically educated people or aesthetic selfexpressiveness, as suggested by Chapman (1972), includes the choices which come implicitly or explicitly from the previous knowing and understanding of the existing (Arnold, 1986). According to Arnold (1995), artistic expression, if observed in the context of communication, results from dancers' professionalism because it will be up to their abilities to express what a choreographer has imagined.

In this research, the subjective experience of freedom of artistic expression is defined by three criteria, as follows: the freedom to use space (referring to a choice of space that will be used while the choreography is being performed), the freedom to use different dance figures (referring to the choice of various figures by a choreographer for specific choreographies) and the freedom to express emotions (referring to the type and intensity of emotional content that a choreographer has chosen to incorporate into each choreography). On the basis of these three criteria, how each of investigated dance forms allows dancers to use different figures, dancing space and how free they are to express their emotions through a form of dance is examined. In our research, the female choreographers who will also be performers were chosen in order to overcome an obstacle concerning artistic expression, as discussed by Arnold (1995), whereby an artistic expression results from dancers' professionalism be- 
cause their ability will not affect only the expression of certain content required by the dance, but also what the choreographer has imagined.

The main question of this paper concerns a dancer's freedom of artistic expression, more precisely, what is an audience's subjective experience of an expressed freedom and is the subjective experience of freedom of artistic expression related to the characteristics of the form of dance within which the choreography is performed?

The previous research showed that there is a connection between the subjective experience and objective characteristics of art work (Arnheim, 1969; Marković, 2007; Marković, Janković, \& Subotić, 2002; Marković \& Radonjić, 2008; Vukadinović, 2008; Radonjić, 2004).

In the perception of an art work, in addition to the detection of objective and explicit characteristics whose aim is to obtain information about the physical characteristics of stimulation, there are other characteristics which are not directly given in stimulation, but they are assigned by an audience and relate to the subjective experience of stimulation (Marković \& Radonjić, 2008). In the previous study (Vukadinović, 2008) dealing with the relationship between subjective and objective categorization of different forms of dance, including classical ballet, modern ballet and flamenco, showed that the objective classification of various forms of artistic dance is subjectively relevant. There is an ideal accord between the subjective and objective categorizations of different forms of artistic dance. Subjective categorization is based on certain formal characteristics in each of the investigated forms of artistic dance. General formal descriptions of various forms of artistic dance through the characteristics, such as figural goodness, dance technique, dynamics of movement, elegance of movement and complexity of movement, overlap with the subjective experience of different forms of artistic dance.

Since subjective categorization of dance is based on its formal properties (Vukadinović, 2008), the perspective of the cultural psychology of creativity (Glăvaneu, 2010) seems to be the most adequate and comprehensive methodological and conceptual framework for this research, because it emphasizes on the dialogical relationships between new artefact (choreography), creator (choreographer), existing artefact (dance form) and other (audience).

According to Glăvaneu, (2010) creation (new artefact) is connected to and is in a dialogical relationship with the existing artefacts i.e. with the previous knowledge, cultural repertoires and it has been recognised in earlier studies (Feldman, 1974; Liep, 2001; Negus \& Pickering, 2004) with tradition. The system of symbols and norms that constitute each dance form and which are expressed and communicated to the audience through formal characteristics that each particular dance form has, means that the dance forms in this paper can be understood as being representative of existing artefacts.

Therefore serving the purposes of investigating the participants' estimation of their subjective experience of the freedom of the artistic expression, we have selected three dance forms, (classical ballet, modern ballet and flamenco) each with different formal characteristics due to the cultural and historical contexts from which each of these forms emerges.

Due to the different cultural and historical contexts behind each dance form (existing artefact) and their dialogical connections (Glăvaneu, 2010) to the audience (other), it could be expected that an audience's subjective experience of freedom of artistic expression would vary. Previous studies (Mandarić \& Pflug, 2012; Pflug, 2011; Vukadinović, 2010, 2011), which have suggested that an audience's aesthetic experience differs according to the dance form, support this hypothesis.

It may also be expected that a particular dance form will influence, through its formal characteristics, not only how certain choreographies will be created but also what an audience's subjective experience of freedom of artistic expression will be.

For instance, one may assume that ballet may act as an obstacle to a dancers' freedom of expression due to its formal characteristics including precisely defined positions of arms and legs, a pointé, and symmetrical geometric forms which the choreography tends to, as well as emphasizing clarity, harmony, symmetry and order in movement ( $\mathrm{Au}$, 2002; Laws, 2002). Likewise, modern ballet may be 
considered to be a freer form of dance due to its expression but also owing to its formal characteristics, including floor work and various types of movement (falling, sitting, lying, kneeling), movements based on the principle of contraction and release, and a specific approach to the expression of feelings not leaning to a strict linear narrative or pantomime of ballet storytelling ( $\mathrm{Au}, 2002$; Duncan, 1981; Graham, 1991; Jowitt, 1994). Finally, it can be assumed that flamenco, characterized by the ornate twisting movement of hands and specific foot work, and especially by a request to show their emotions (Candelori \& Díaz, 1998) is likely to be assessed highly according to the criterion of freedom to express emotions.

Placing the problem into the context of cultural psychology of creativity (Glăvaneu, 2010) and by investigating an audience's subjective experience of the freedom of artistic expression of different dance forms, this research attempts to reveal and understand the complex dialogical connections between self (choreographer) and other (audience), previous knowledge (particular dance forms) and new creation (choreography) as a dynamic whole.

\section{Method}

This research aims to check whether there are differences in the participants' assessment of their subjective experience of the freedom of artistic expression concerning various dance forms, and if any, what kind of differences they are.

\section{Participants}

There were 69 students from the Psychology Department of The Faculty of Philosophy in Novi Sad participating in this research. Among them there were 23 young men and 46 women, aged 22 on average. Regarding cultural context, all the participants were from the same city and from the same socio-cultural milieu, which supports, in both institutional and media sense (through electronic and printed media), different cultural activities: theatre performances, art exhibitions and prominent festivals. The main criterion for the recruitment of participants was that the participants had not had any previous direct experience with dance training of examined dance forms, and second, that they had observed between three and ten performances of each examined dance form before. The preference to the certain dance form was not controlled as a variable in this research. All the participants participated voluntarily in the research. They did not receive course credit or payment.

For each of different forms of dance there were also three professional female choreographers, aged 25 on average and with around eight years of professional experience in dancing and choreography. These choreographers made three choreographies within their dance form and acted as performers in these choreographies as well.

\section{Stimuli}

The Stimuli consisted of nine dance choreographies, which were as follows: three dance choreographies for classical ballet, three for modern ballet and three for flamenco. Each of these nine choreographies lasted for 120 seconds, and the recorded rhythmic matrix controlled the duration. Due to various dance performers, dance forms and the space where stimulus was recorded, the research was divided into three parts. The choreographies were shown to the participants in the form of audiovisual recordings. In the first part there were the choreographies of classical ballet. The second part contained the choreographies of modern ballet and lastly flamenco.

\section{Instrument}

A seven point (from 1 to 7 ) rating scale was used to measure the freedom of artistic expression. The instrument consisted of 3 seven-point rating scales: a) freedom to use space, b) freedom to use different dance figures and c) freedom to express emotions.

\section{Procedure}

The choreographies were presented using a video projector in the form of a visual and auditory re- 
cording according to the order established beforehand. The participants observed the recordings in groups, and having finished watching each recording, they immediately made assessments. The participants were asked to direct their attention and ratings towards the freedom of artistic expression in the dance movements. The time allotted for the ratings after each choreography was one minute.

\section{Task for participants}

Having observed the dance performance, the participants' task was to assess choreographies in each part of the research by seven-point scales (from 1 to 7) following the three criteria for the freedom of artistic expression: freedom to use space, freedom to use different dance figures and freedom to express emotions.

The first independent variable is dance form (ballet, modern ballet, flamenco). The other independent variable is the choreography within each dance form (three dance forms) and for each form this variable has three levels. There were nine choreographies in total. The dependent variables are assessments of the participants for each of the nine choreographies by the criteria of the freedom of artistic expression: freedom to use space, freedom to use different dance figures and freedom to express emotions.

This design was repeated with all subjects, which means that all participants watched and evaluated using the three criteria of the freedom of artistic expression in all nine choreographies.

\section{Results}

The results of the analysis of variance will be shown through three types of analysis. The differences between the observed dance forms by every dependent variable will be discussed within the overview of the results that follow. There will then be an analysis of the differences between the choreographies within each dance form by dependent variables. Finally, the differences between dependent variables within each dance will be analyzed.
The results of the analysis of variance - the differences between investigated dance forms

Generally speaking, the results show that the participants' subjective experience of the freedom of artistic expression is statistically significantly different regarding the various forms of dance. This is shown by the fact that the main effect of the form of dance on the participants' assessment for all given criteria for freedom of artistic expression was statistically significant $F(2,63)=19.081, p<0.001$.

\section{Freedom to use space}

As far as the freedom to use space is concerned, the results showed that the effect of dance form $F(2,68)=19.915, p<0.001$ was statistically significant. The Least Significant Difference test showed that modern ballet $(M=5.23, S D=1.39)$ is assessed by statistically significantly higher values $(p<0.001)$ in comparison with both classical ballet $(M=4.19, S D=1.32)$ and flamenco $(M=4.13$, $S D=1.43)$, conversely the participants' judgement by the criterion of freedom to use space between the choreographies of classical ballet and flamenco does not differ significantly.

Freedom to use different dance figures

Regarding the freedom to use different dance figures, the results showed that the effect of dance form $F(2,68)=29.317, p<0.001$ was statistically significant. The participants' assessment for this criterion differs statistically significantly for these three dance forms. The Least Significant Difference test showed $(p<0.001)$ that the most freedom to use different dance figures is present in modern ballet $(M=5.27, S D=1.39)$, then in flamenco $(M=4.49, S D=1.42)$, and the least is in ballet $(\mathrm{M}=4.01, \mathrm{SD}=1.31)$.

Freedom to express emotions

Regarding freedom to express emotions, the results showed that the effect of dance form $F(2,68)=$ 
$34.544, p<0.001)$ was statistically significant. The Least Significant Difference test showed $(p<0.001)$ that classical ballet $(M=3.53, S D=1.45)$ is assessed by statistically less significant values in comparison with modern ballet $(\mathrm{M}=4.87, \mathrm{SD}=$ 1.47) and flamenco $(M=5, S D=1.42)$, whereas the participants' assessment of freedom to express emotions between modern ballet and flamenco did not show statistically significant results.

The results of analysis of variance - the differences between choreographies within each dance form by dependent variables

\section{Classical ballet}

Regarding classical ballet, the results showed that the effect of choreography on the assessment of the freedom of artistic expression, in all the abovementioned criteria, $(6,63)=6.341, p<0.001$ was statistically significant.

Concerning the effect of choreography in terms of freedom to use space $F(2,68)=9.965, p<0.001)$ was statistically significant. The Least Significant Difference test showed $(p<0.001)$ that the greatest freedom to use space is present in the second choreography $(M=4.65, S D=1.63)$, then in the first $(M=4.21, S D=1.56)$, and the least freedom to use space is present in the third choreography of this dance form $(M=3.71, S D=1.79)$.

The effect of choreography on the assessment of freedom to use different dance figures was statistically significant $F(2,68)=16.908$, $p<0.001)$. The Least Significant Difference test shows $(p<0.0001)$ that the first choreography for classical ballet $(M=3.50, S D=1.71)$ is graded by statistically significantly lower values in comparison with the second $(M=4.53, S D=1.70)$ and the third choreography $(M=4.34, S D=1.67)$, whereas the participants' assessment concerning the criterion of freedom to use different figures does not show statistically significant differences between the second and third choreographies.

The effect of choreography on the assessment of freedom to express emotions was statistically significant $F(2,68)=9.741, p<0.001$. The
Least Significant Difference test shows $(p<0.001)$ that the second choreography of classical ballet $(\mathrm{M}=4.02, \mathrm{SD}=1.72)$ is graded by statistically significantly higher values in comparison with the first $(M=3.47, S D=1.85)$ and the third choreography $(M=3.08, S D=1.77)$, whereas the participants' assessment regarding the criterion of freedom to express emotions does not show statistically significant differences between the first and third choreographies.

\section{Modern ballet}

The results show that concerning the effect of choreography on the assessment of freedom of artistic expression when regarding modern ballet $F(6,63)=6.384$, $p<0.001$ was statistically significant.

The effect of choreography on the assessment of freedom to use space is not statistically significant.

The effect of choreography on the assessment of freedom to use different dance figures was statistically significant $F(2,68)=16.776, p<0.001$. The Least Significant Difference test showed $(p<0.001)$ that the biggest freedom to use different dance figures was present in the first choreography $(M=5.79, S D=1.45)$. The freedom to use different dance figures is lower for the third choreography $(M=5.23, S D=1.64)$, and the lowest for the second choreography $(M=4.79, S D=1.76)$.

The effect of choreography on the assessment of freedom to express emotions was statistically significant $F(2,68)=9.681, p<0.001)$. The Least Significant Difference test shows $(p<0.001)$ that the second choreography of modern ballet $(\mathrm{M}=4.33, \mathrm{SD}=1.77)$ has statistically significantly lower values in comparison with the first $(M=5.17$, $S D=1.67)$ and the third choreography $(M=5.13$, $S D=1.93)$, whereas the participants' assessment regarding the criterion of freedom to express emotions does not show statistically significant differences between the first and third choreographies.

\section{Flamenco}

The results show that the effect of choreography on the assessment of freedom of artistic expression 
regarding flamenco was statistically significant $F(6,63)=6.449, p<0.001$.

Concerning the freedom to use space, the effect of choreography was statistically significant $(F(2,68)=16.908, p<0.001)$. The Least Significant Difference test shows $(p<0.001)$ that the first choreography of flamenco $(\mathrm{M}=3.50, \mathrm{SD}=1.71)$ is graded statistically significantly lower in comparison with the second $(M=4.53, S D=1.70)$ and the third choreography $(M=4.34, S D=1.67)$, whereas the participants' assessment by the criterion of freedom to use space does not show statistically significant differences between the second and third choreographies.

The effect of choreography on the assessment of freedom to use different dance figures was statistically significant $F(2,68)=9.021, p<0.001$. The Least Significant Difference test shows $(p<0.001)$ that the first choreography of flamenco $(M=4.014$, $S D=1.67)$ is graded by statistically significantly lower values in comparison with the second $(M=4.85, S D=1.63)$ and the third choreography $(M=4.60, S D=1.84)$, whereas the participants' assessment regarding the criterion of freedom to use different dance figures does not show statistically significant differences between the second and third choreographies.

The effect of the choreography on the assessment of freedom to express emotions was not statistically significant.

\section{The results of the analysis of variance - the differences between dependent variables within every dance form}

\section{Classical ballet}

The results of the analysis of variance show that the assessments in the case of classical ballet had statistically significant differences in terms of the freedom of artistic expression $F(2,68)=14.078$, $p<0.001)$. The Least Significant Difference test shows $(p<0.001)$ that freedom to express emotions $(\mathrm{M}=3.53, \mathrm{SD}=1.45)$ is assessed by statistically significantly lower values in comparison with the freedom to use space $(M=4.19, S D=1.32)$ and the freedom to use different dance figures $(M=4$, $S D=1.31)$, whereas the participants' assessment regarding the criteria of freedom to use different dance figures and the freedom to use space does not differ significantly.

\section{Modern ballet}

The results of the analysis of variance show that the differences in the assessments of the investigated criterion of freedom of artistic expression regarding modern ballet are statistically significant $F(2,68)$ $=5.037, p<0.008$. The Least Significant Difference test showed $(p<0.001)$ that freedom to express emotions $(M=4.87, S D=1.47)$ was graded by statistically significantly lower values in comparison in terms of both the freedom to use space ( $M=$ $5.23, S D=1.39)$ and the freedom to use different dance figures $(M=5.27, S D=1.39)$, whereas the participants' assessment of the criteria of freedom to use different dance figures and freedom to use space does not differ significantly.

\section{Flamenco}

The results of the analysis of variance show that the differences in assessments by the investigated criterion of freedom of artistic expression regarding flamenco are statistically significant $F(2,68)$ $=19.921, p<0.001$. The Least Significant Difference test shows $(p<0.001)$ that the freedom to express emotions $(M=5, S D=1.42)$ is graded the highest, followed by the freedom to use different dance figures $(M=4.49, S D=1.42)$ while the freedom to use space is graded the lowest $(M=4.13$, $\mathrm{SD}=1.43)$.

\section{Discussion and Conclusion}

The obtained results based on the participants' assessment of their subjective experience of the freedom of artistic expression, seem to indicate that the discoveries of this research are not only in favour of more research on creativity that takes cultural perspectives into consideration (Glăvaneu, 2010), but that they can also be interpreted more com- 
pletely and comprehensibly in the methodological and conceptual framework of cultural psychology. According to Glăvaneu (2010), in the cultural tetradic framework of creativity new artefact (creation) emerges within the relationship between self (creator) and other (community), whereas all three of them are in dialogue with the existing artefacts (culture), i.e. with the existing body of cultural artefacts, symbols and established norms. Glăvaneu (2010, p. 87) pointed out that creativity cannot exist out of the relationship with other people and that creativity has to be inside the cultural setting since every new artefact needs constant meaningmaking process. In the context of this research, creation (new artefact) relates to the specific choreographies of the certain dance forms, made by choreographer's (creator) respecting the rules and in accordance with the norms and ideas of a dance form they belong to. The system of symbols and norms that constitute each dance form and which are expressed through the formal characteristics of each of them (dance form), were understood as being representative of existing artefacts. The focus of the research was primarily placed on participants (others).

As one of the basic ideas of the cultural psychology of creativity within We-paradigm is to reveal dialogical connections between self (creator) and other (community), previous knowledge (existing artefacts) and creation (Glăvaneu, 2010), the aim of this research was to examine how participants (other) assess the subjective experiences of the choreographies (new artefacts) of these dance forms (existing artefacts).

The results observed in the context of cultural perspective (Glăvaneu, 2010) suggested that the formal characteristics that represent certain dance forms are not only one of the determinants of creativity but also the bearers and transmitters of certain meanings that are communicated through the dance form. More precisely, following the obtained results based on the participants' assessment of their subjective experience of the freedom of artistic expression, it is seen that the level of freedom allowed by different dance forms is different. Modern ballet is the dance form that the participants assessed as being the one which allows the highest extent of freedom to use space and freedom to use different figures. However, modern ballet, along with flamenco, are the dance forms with the highest level of freedom to express emotions according to participants' subjective experience. Concerning the formal characteristics of modern ballet, these findings were anticipated. They were also likely to be obtained keeping in mind the tendency of modern ballet to focus on the principles of spiritual and formal freedom (Duncan, 1981; Graham, 1991), and aim to express an individual and society (Au, 2002; Huxley, 1994; Jowitt, 1994; Press, 2002). With regard to flamenco, the results showed the high assessment by the criterion of freedom to express emotions. The results were anticipated since communicating feelings is not just a basic characteristic of flamenco but the key aim of this dance (Gómez Muñoz, 2008) since its beginnings.

These results point out the importance of considering the cultural and historical perspectives of particular dance forms while interpreting an audience's assessment of the freedom of the artistic expression, since according to Moran and JohnSteiner (2003) creators use culturally constructed symbols to produce new cultural artefact, and that interpretations (Montuory \& Purser, 1995), which every new artefact needs, are context-depended.

The obtained results about the significant effects of choreography on the assessment of the freedom of artistic expression also indicate the importance of observing the results in the context of cultural psychology of creativity. They have revealed that the choreographies of classical ballet have an influence on the participants' assessment regarding all three examined criteria of the freedom of artistic expression. Our results point to the fact that choreographies of classical ballet determine how much space will be used, how many different dance figures will be performed and to what extent feelings will be expressed. The choreographies of modern ballet influence the participants' assessment only in the case of freedom to use different figures and freedom to express emotions. The choreographies of flamenco influence the participants' assessment only in the case of the freedom to use space and 
the freedom to use different dance figures. The dance forms of modern ballet and flamenco may have an influence on the making of choreographies through their formal characteristics. The results show that the number of different figures depends on the choreographies of both modern ballet and flamenco. Likewise the choreography influences the extent to which emotions will be expressed in modern ballet, and the way in which the space in flamenco will be used.

On the one hand, Glăvaneu (2010) refers to strong links between the creative outcome and the identity of the creator beside the role of other and cultural setting. In this sense we may assume that the previously mentioned obtained results relate to the significant effect of choreography on the assessment of the freedom of artistic expression and that they are probably formed to some extent by the choice of choreographer within the given dance form.

On the other hand, there are interesting findings about the fact that the assessments of freedom to use space in the choreographies of modern ballet do not differ significantly, which could be linked to the fact that the freedom to use space is one of the basic characteristics of this dance form. This is seen in its formal characteristics and emanates from the idea of the dance itself. It can also be assumed that the same exists in flamenco where the assessments of freedom to express emotions in the choreographies do not differ significantly. This confirms that a strong expression of emotions is one of the basic characteristics of flamenco and is recognized by the participants, and this along with specific techniques, represents the basic idea and aim of this dance form. It can be concluded that taking a broader approach when investigating creativity proposed by Glăvaneu (2010) enables us to understand more clearly the importance of each aspect and their dialogical connection in the tetradic framework within the cultural psychology of creativity. The significant effect of choreography, as well as the significant effect of a dance form on the audience and their estimations of the freedom of the artistic expression, points out the links between creative outcome (choreographies) and others (par- ticipants). It also highlights the links with and the role of previous knowledge and the existing body of symbols and established norms (dance forms).

The following analysis of participants' assessment by dependent variables or by all three of the examined criteria concerning the freedom of artistic expression within each dance form refers to the specific existing body of symbols and established norms. This outlines a context of each of the examined dance forms and is expressed and communicated to the audience through the formal characteristics of the dance.

Within the dance form of classical ballet, the freedom to express emotions was assessed with significantly lower value in comparison with the other two criteria for assessing the freedom of artistic expression. Although dramatic action is emphasized, the extent of freedom to express emotions is likely to be assessed the lowest since ballet requires harmony, symmetry, discipline and restraint from the ballet dancers (Au, 2002; Laws, 2002). This is reflected through the formal characteristics of ballet, strict forms of movement, à pointe, precisely defined body positions etc.

Within the dance form of modern ballet the freedom to express emotions is, interestingly, assessed with significantly lower value in comparison with the other two criteria. Such a result could have been expected keeping in mind the basic concepts of modern ballet, which are communicated through its formal characteristics of expressing human existence (Au, 2002; Huxley, 1994; Jowitt, 1994; Press \& Warburton, 2007) and the complexity of human nature (Duncan, 1981; Graham, 1991; Huxley, 1994; Jowitt, 1994). It may be understood that the freedom to use space and the freedom to use dance figures are significant pillars of these fundamental ideas of modern ballet, since it has previously been showed (Camurri, Lagerlöf, \& Volpe, 2003) that the expression of basic emotions (anger, fear, grief and joy) are easily recognizable in modern ballet.

Within the dance form of flamenco the freedom to express emotions is assessed the highest, whereas the freedom to use space is assessed with the lowest rating. These results can be interpreted keeping in mind the cultural and historical contexts of this 
dance form. The fact that flamenco attained the highest assessment of freedom to express emotions could have been expected, since the art of flamenco insists on strong expression of emotions. The fact that flamenco had the lowest assessment of freedom to use space probably resulted from the fact that flamenco is characterized with dancing in a small space among friends and other flamenco dancers (Candelori \& Díaz, 1998; Grande, 1987).

On the basis of what has been shown in our results, it can be concluded that the dance form is understood as an existing body of symbols and established norms (existing artefact), through its formal characteristics, which influences not only the way of creating particular choreography (new artefact), the freedom to use space, different dance figures and to express emotions, but also how an audience (other) will experience this. This result confirms the idea proposed by (Glăvaneu, 2010) that from the perspective of cultural psychology, creativity should be understood as a complex socio-cultural-psychological process. In the context of this research it means that the creative process of making choreography does not depend only on the components of creative performance related to the creator, which include domain-relevant skills, creativity-relevant skills and task motivation (Amabile, 1983), but also on a broader cultural context (Glăvaneu, 2010) reflected through the formal characteristics of a particular dance for which the choreography is created.

In the tetradic framework within the cultural psychology of creativity approach some interesting aspects of the relationship between creator and previous knowledge (existing artefacts) can be highlighted. For example, regarding domain relevant skills, which Amabile (1983) sees as the knowledge of the creator about the domain, technical skills required and special domain-relevant "talent" was shown (Runco, 2004) that experts belonging to certain fields are often inflexible and frequently overlook original solutions, because they rely on gained and established knowledge so getting to know certain domains or knowledge can often inhibit creative thinking. Similarly, Amabile (1983) recognizes that the component of domain relevant skills often includes the performance "script" meaning previously determined steps for performing certain tasks or solving certain problems in a certain domain. Also, speaking of indicators for aesthetic education and creativity Zanella (2007), amongst others, point out the problems of stereotyped forms typical in everyday life that blind us of the possibility of differences. Therefore it can be assumed that good knowledge of a particular dance form, its rules and ideals on which its performance is based and the formal characteristics coming from this idea, allow considerable creativity but also shape individual creativity and impose limits to the freedom of artistic expression. For instance, the desired strong emotional expressiveness in flamenco will be completely inadequate for classical ballet. Some types of fall and standing up are characteristic to modern ballet, but they will not be suitable for a strong form of classical ballet. Classical ballet tends to harmony, order and symmetry, especially in hand movements, but these tendencies would be tedious and inadequate for flamenco, as it prefers ornate twisting movements of hands.

For a better understanding of dance phenomenon, important advantages of the cultural psychology of creativity as conceptual and methodological frameworks applied in this research can be pointed out. Firstly, the cultural psychology of creativity perspective understands elements of tetradic framework as a dynamic whole, secondly, it supports the multiplicity of "fields" and "domains" in which the creator is involved, and thirdly the notion of existing artefact (Glăvaneu, 2010, p. 89) “...incorporates all forms of material and symbolic resources that inform the creative process and these can be drawn from several "domains", as well as common-sense knowledge".

When this is applied to dance, one of the possible approaches to overcome the potential problems between creator and "existing knowledge", and the limits in creating dance choreography from the rules and ideas on which the performance of particular dance form is based on, is to incorporate and adapt certain elements from one dance form to another. For instance, the fusion of various elements of modern ballet and contemporary dance 
with flamenco movements, especially within the traditional concept of flamenco, has been recognized for a while as one of the tendencies in flamenco (Gómez Muñoz, 2008).

Certain dance forms are less and others are more appropriate for incorporating and adapting to certain elements from other dance forms. However, the attempt to overcome limits resulting from notional concept reflected in the formal characteristics of a particular dance form sometimes leads to forming completely new approaches in dance. Therefore it is interesting to notice that the idea of modern ballet resulted from the need to be free from the strict rules of classical ballet, from the need to separate the spiritual component from technique and to emphasize the principle of spiritual and formal freedom (Adshead-Lansdale, 1994; Au, 2002; Duncan, 1981; Graham, 1991; Jowitt, 1994), whereas the idea of contemporary dance is marked as "renaissance" in modern ballet (Adshead-Lansdale, 1994; Koenig, 1980).

The importance of a dynamical and dialogical relationship of elements of tetradic model within the cultural psychology of creativity approach (Glăvaneu, 2010) can be noticed regarding not only a better understanding of a dance phenomenon but dancing practice as well. In that sense, the results of our research showed that the dance form (existing artefact), through its formal characteristics, influences not only how certain choreography will be created, but also how the audience (other) will experience that choreography (new artefact). This may be important for dancing practice or especially for dance composition (Hagood \& Kahlich, 2007) where creative processes within making choreography are analysed. Having in mind the emphasis that Glăvaneu (2010) puts on the role of the other (community) as a provider of criteria for evaluating creativity, our study may also be important for choreographers of the observed dance forms, since it points out how an audience (other) may subjectively experience the freedom of artistic expression of certain dance forms which may have further significance for creating choreographies that will have a more profound effect on them.
Finally, based on the results of an audience's estimation of the freedom of the artistic expression, it may be concluded that artistic expression should be understood as communication in the performing art of dance, as was suggested before (Arnold, 1995; Vukadinović \& Marković, 2012). It may also be concluded that dance, observed as artistic discipline established on a specific existing body of symbols and norms, where movements are organised and formalised, gives structure and therefore imposes limits requiring form and shape in creative expression. In the case of the creator as well as regarding the performer, the freedom of artistic expression is influenced by the form of dance, and the rules for performing it. In that sense, even though freedom, seen in its broadest sense, represents one of the aspects of the purpose of dance, the conclusion that art, and thus dance "brings freedom in using oneself" (Ognjenović, 2003 , p. 238) should be considered with reservation, at least in the case of artistic dance and the freedom of artistic expression which we dealt within this study. Unlike a dance as an artistic category, a spontaneous dance provides a greater freedom of expression but it gives neither form nor structure. Since we dealt with artistic dance, we will limit our conclusion to this domain.

The positioning of the problem and result of this research in the context of the cultural psychology of creativity helped on the better understanding of the dialogical relationship between the dance form and an audience. The dialogical relationship between the dance form and an audience is contained (Vukadinović, 2008) in the existence of the ideal accord between audience's subjective experience of particular dance and dance form to which estimated choreography belongs to.

Unlike dance, in other artistic disciplines, such as music, (Pejić \& Pflug, 2010) the existence of an accord between subjective categorization and musical artistic direction was not shown. Additionally, in the case of the subjective experience of paintings belonging to the different genres of the $20^{\text {th }}$ century painting, it was shown (Radonjić \& Marković, 2004) that with formal characteristics, the content is also a significant factor in subjective experience. This comparison of 
the findings obtained for dance with the findings for other artistic disciplines leads to the conclusion of taking cultural context into consideration, especially while studying a "universal cultural phenomenon" (Hagendoorn, 2011, p. 514) like dance.

On the whole, it can be concluded that the findings of this study support the importance of the dynamical and dialogical relationship of elements of the tetradic model within the cultural psychology of creativity approach (Glăvaneu, 2010). Applied to dance as an artistic discipline this approach encourages attempts to reveal and understand complex dialogical connections between self (choreographer) and other (audience), previous knowledge (particular dance forms) and new creation (choreography) as a dynamic whole.

This paper gives a brighter insight into the possible connections between an audience's subjective experience of the freedom of artistic expression in dance and different dance forms to which a particular choreography belongs to. Even though this research provided answers to some questions regarding the complex phenomenon of dance, investigating how different socio-cultural context of an audience, i.e. how an audience from different countries estimate different dance forms, would be fruitful, since in this research an audience belonged to the same socio-cultural context. Also, questions such as - whether members of an audience, who are trained in particular dance forms estimate differently, or, how dialogical processes between choreographers (creator) and the existing body of knowledge (particular dance form) partake in creating choreography (new artefact), etc., are left to be answered and empirically tested. In that sense these other aspects, concerning the dynamical and dialogical relationship of elements of the tetradic model within a cultural psychology of creativity approach applied to dance could be the inspiration for future research.

\section{References}

Adshead, J., Briginshaw,V. A., Hodgens, P., \& Huxley, M. R. (1982). A chart of skills and concepts for dance. Journal of Aesthetic Education, 16(3), 49-61.
Adshead-Lansdale, J. (1994). The dance history literature: A readesr's guide. In J. Adshead-Lansdale \& J. Layson (Eds.), Dance history: An introduction (pp. 32-41). London/New York: Routledge.

Adshead-Lansdale, J., \& Layson, J. (Eds.). (1994). Dance history: An introduction. London/New York: Routledge.

Amabile, T. (1983). The social psychology of creativity: A componential conceptualization. Journal of Personality and Social Psychology, 45(2), 357-376.

Arnheim, R. (1966). Towards a psychology of art: Collected essays. Berkeley: University of California Press.

Arnheim, R. (1969). Art and visual perception. Berkely/ Los Angeles: University of California Press.

Arnold, P. J. (1986). Creativity, self-expression, and dance. Journal of Aesthetic Education, 20(3), 49-58.

Arnold, P. J. (1995). Objectivity, expression, and communication in dance as a performing art. Journal of Aesthetic Education, 29(1), 61-68.

$\mathrm{Au}, \mathrm{S}$. (2002). Ballet and modern dance. London: Thames $\&$ Hudson World of Art.

Biddle, S., Fox, K., \& Boutcher, S. H. (2000). Physical activity and psychological well- being. London: Routledge.

Biddle, S., \& Mutrie, N. (2001). Psychological outcomes of physical activity. In S. Biddle \& N. Mutrie (Eds.), Psychology of physical activity (pp. 167-202). London: Routledge.

Blom, A., \& Chaplin, L. (2000). The moment of movement. London: Dance Books.

Camurri, A., Lagerlöf, I., \& Volpe, G. (2003). Recognizing emotion from dance movement: Comparison of spectator recognition and automated techniques. International Journal of Human- Computer Studies, 59(1-2), 213-225.

Candelori, N., \& Díaz, N. F. (1998). Il flamenco [Flamenco]. Milano: Xenia.

Chapman, O. M. (1972). Creative dance: Some implications of the concept. The Laban Art of Movement Guild Magazine, 49, 15-19.

DeLahunta, S. (2004, September). Choreography and cognition: A joint research project. In J. P. Fróis, P. Andrade, \& J. F. Marques (Eds.), Proceedings of the XVIII Congress of the International Association of Empirical Aesthetics (pp. 169-173). Lisbon: Calouste Gulbenkian Fondation. 
Duncan, I. (1981). Isadora speaks. San Francisco: City Light Books.

Feldman, D. H. (1974). The developmental approach: Universal to unique. In S. Rosner \& L. E. Abt (Eds.), Essays in creativity (pp. 47-85). Croton-onHudson: North River Press.

Fenemor, A. (2003). On being moved by performance. Performance Research, 8(4), 107-114.

Fraleigh, S. H. (1999). Family resemblance. In S. H. Fraleigh \& P. Haristein (Eds.), Research in dance: Evolving modes of inquiry (pp. 3-21). Pennsylvania: University of Pittsburgh Press.

Golomer, E., \& Dupui, P. (2000). Spectral Analysis of adult dancers sways: Sex and interaction visionproprioception. International Journal of Neuroscience, 105(1-4), $15-26$.

Gómez Muñoz, R. (2008). El baile flamenco hoy [Flamenco dance today].Junta de Andalucía: Rutas Flamencas, 45-48.

Glăvaneu, V. (2010). Paradigms in the study of creativity: Introducing the perspective of cultural psychology. New Ideas in Psychology, 28(1), 79-93.

Graham, M. (1991). Blood memory. New York: Doubleday.

Grande, F. (1987). Memoria del flamenco I [The Memory of Flamenco I]. Madrid: Espasa Calpe, S.A.

Hagood, T. K., \& Kahlich, L. C. (2007). Research in Choreography. In L. Bresler (Ed.), International handbook of research in arts education (pp. 517-528). New York: Springer.

Hamby, C. (1984). Dance and the dancer. British Journal of Aesthetics, 24(1), 39-46.

Hugel, F., Cadopi, M., Kohler, F., \& Perrin, P. (1999). Postural control of ballet dancers: A specific use of visual input for artistic purposes. International Journal of Sports Medicine, 20(2), 86-92.

Huxley, M. (1994). European early modern dance. In J. Adshead-Lansdale \& J. Layson (Eds.), Dance history: An introduction (pp. 151-168). London/New York: Routledge.

Hagendoorn, I. (2011). Dance, choreography and the brain. In D. Melcher \& F. Bacci (Eds.), Art and the senses (pp. 513-527). Oxford: Oxford University Press.

Jowitt, D. (1994). Expression and expressionism in American modern dance. In J. Adshead-Lansdale
\& J. Layson (Eds.), Dance history: An introduction (pp. 169-181). London/New York: Routledge.

Kent, A., Camner, J., \& Camner, C. (1984). The dancers' body book. New York: HarperCollins Publisher, Inc.

Koenig, J. F. (1980). La danse contemporaine [Contemporary dance]. Paris: Fayard.

Kogan, N. (2002). Careers in the performing arts: A psychological perspective. Creativity Research Journal, 14(1), 1-16.

Layson, J. (1994). Historical perspectives in the study of dance. In J. Adshead-Lansdale \& J. Layson (Eds.), Dance history: An introduction (pp. 4-17). London/ New York: Routledge.

Laws, K. (2002). Physics and the art of dance: Understanding movement. Oxford: University Press.

Liep, J. (2001). [Introduction]. In J. Liep (Ed.), Locating cultural creativity (pp. 1-13). London: Pluto Press.

Marković, S. (2007). Opažanje dobre forme [Perception of figural goodness]. Beograd: Univerzitet $\mathrm{u}$ Beogradu.

Marković, S., Janković, D., \& Subotić, I. (2002) Implicitna i eksplicitna svojstva vizuelnog geštalta [Implicit and explicit features of visual Gestalt]. Psihološka istraživanja, 11-12, 75-112.

Mandarić, S., \& Pflug, A. (2012, February). Razlike u estetskoj proceni latino - američkih i standardnih plesova [The differences in aesthetic estimation of Latin and standard dances]. Empirijska istraživanja u psihologiji, XVIII naučni skup, Filozofski fakultet, Univerzitet u Beogradu, Beograd.

Marković, S., \& Radonjić, A. (2008). Implicit and explicit features of paintings. Spatial Vision, 21(3-5), $229-259$

McFee, G. (1992). Understanding dance. London/New York: Routledge.

Meekums, B. (2005). Dance movement therapy: A creative psychotherapeutic approach. London: Sage.

Montero, B. (2006). Proprioception as an aesthetic sense. The Journal of Aesthetics and Art Criticism, 64(2), 231-242.

Montuory, A., \& Purser, R., (1995). Deconstructing the lone genius myth: Toward a contextual view of creativity. Journal of Humanistic Psychology, 35(3), 69-112.

Moran, S., \& John-Steiner, M. (2003). Creativity in the making: Vygotsky's contemporary contribution to 
the dialectic of development and creativity. In R. K. Sawyer et al. (Eds.), Creativity and development (pp. 61-90). Oxford: Oxford University Press.

Mullis, E. (2006). Performative somaesthetics: Principles and scope. Journal of Aesthetic Education, 40(4), 104-117.

Negus, K., \& Pickering, M. (2004). Creativity, communication and cultural value. London: Sage.

Ognjenović, P. (2003). Psihološka teorija umetnosti [The psychological theory of art]. Beograd: Gutenbergova Galaksija.

Pallaro, P. (1999). Authentic movement. Essays by Mary Starks Whitehouse, Janet Adler, and Joan Chodorow. London/Philadelphia: Jessica Kingsley Publishers.

Pallaro, P. (2007). Authentic movement. Moving the body, moving the self, being moved. A collected of essays (Vol. 2). London/Philadelphia: Jessica Kingsley Publishers.

Pejić, B., \& Pflug, A. (2010, February). Subjektivni doživljaj muzike [Subjective experience of music]. Empirijska istraživanja u psihologiji, XVI naučni skup, Filozofski fakultet, Univerzitet u Beogradu, Beograd.

Pflug, A. (2011, February). Razlike u estetskoj proceni modernog $i$ klasičnog baleta [The differences in aesthetic assessment between modern and classical ballet]. Empirijska istraživanja u psihologiji, XVII naučni skup, Filozofski fakultet, Univerzitet u Beogradu, Beograd.

Press, C. M. (2002). The dancing self: Creativity, modern dance, self-psychology and transformative education. Cresskill, NJ: Hampton Press.

Press, C. M., \& Warburton, E. C. (2007). Creativity research in dance. In L. Bresler (Ed.), International handbook of research in arts education (pp. 1273. 1288). New York: Springer.

Radonjić, A. (2004, February). Subjektivni doživljaj umetničkih slika: uticaj teme $i$ slikarskog pravca [Subjective experience of art paintings: The influence of theme and art movement]. Empirijska istraživanja u psihologiji, X naučni skup, Filozofski fakultet, Univerzitet u Beogradu, Beograd.

Radonjić, A., \& Marković, S. (2004). Subjektivni doživljaj slika koje pripadaju različitim slikarskim pravcima XX veka [Judgement of paintings belonging to different tendencies in the 20th century painting]. Psihologija, 37(4), 549-569.

Runco, M. (2001). Flexibility and originality in children's divergent thinking. The Journal of Psychology, 120(4), 345-352.

Runco, M. (2004). Creativity. Annual Review of Psychology, $55(1), 657$ - 687.

Runco, M., \& Bahleda, M. (1986). Implicit theories of artistic, scientific, and everyday creativity. The Journal of Creative Behavior, 20(2), 93-98.

Stevens, C., Malloch, S., \& McKechnie, S. (2001). Moving mind: The cognitive psychology of contemporary dance. Brolga: An Australian Journal about Dance, 12, 7-14.

Stevens, C., Malloch, S., McKechnie, S., \& Steven, N. (2003). Coreographic cognition: The time-course and phenomenology of creating a dance. Pragmatics \& Cognition, 11(2), 297-326.

Thomas, C. (1980). Aesthetic and dance. American alliance for health, physical education, recreation, and dance. Washington, DC: National Dance Association.

Tufnel, M., \& Crickmay, C. (2006). Body, space, image. London: Dance Books.

Vukadinović, M. (2008). Subjektivni doživljaj različitih tipova umetničke igre [Subjective experience of different types of artistic dance]. Unpublished Master's Thesis, Filozofski fakultet, Univerzitet u Beogradu, Beograd.

Vukadinović, M. (2011, July). Aesthetic experience and emotional identification in the performances of different types of artistic dance. Paper presented at Art, Emotion, and Value, 5th Mediterranean Congress of Aesthetics, Cartagena, Spain. Available at http://www.um.es./vmca/proceedings/docs

Vukadinović, M., \& Marković, S. (2012). Aesthetic experience of dance performances. Psihologija, 45(1), 23-41.

Zanella, A. V. (2007). Educación estética y actividad creativa: herramientas para el desarrollo humano. Universitas Psychologica, 6(3), 483-492. 
